\title{
Determinants of Marriage to First Birth Interval in Birjand, Iran: A Retrospective-Prospective Cohort and Survival Analysis
}

\author{
Mohammadreza Miri ${ }^{1}$, Hakimeh Malaki Moghadam ${ }^{1 * \mathbb{D}}$
}

\begin{abstract}
Objectives: The time-interval between marriage and first childbirth (IMF) can affect fertility and pave the way for decreased fertility in future. This study aimed to determine the effective factors on the time of first childbirth in married women of Birjand, Iran. Materials and Methods: This was a retrospective and prospective cohort study incorporating a total of 180 couples from Birjand who were married in 2011. The data were collected by a checklist and subsequently assessed using survival analysis in STATA13 software. Results: From among the participants, $55.2 \%$ had a child and the rest were censored. The man's age at the time of marriage, the interval between marriage contract to marriage ceremony, type of marriage, wife's place of birth, application of modern methods of contraception, family income per month, and tendency to have a son were the determining factors affecting IMF.

Conclusions: More than half of the freshmen admitted to universities across the country are women who will seek employment after they are graduated. Considerations must be made so that they can have their desired number of children, suitable education, and employment.

Keywords: First birth interval, Childbirth, Survival analysis, Kaplan-Meier survival estimate, Cox regression
\end{abstract}

\section{Introduction}

Population is a component of power and a major contributor to cultural and economic development. In case a country's population crawls into old age, without a consideration for replacement of a younger generation, the country will soon encounter several problems such as employment of foreign nationals instead of the domestic workforce for production purposes (1).

Two hundred years ago, women gave birth to several children. In the mid-19th century, for example, women gave birth to 9 or more children in the United States or Australia up until their fertility period ended. A woman had an average delivery of 6 children. The average is currently less than 2 per woman in the same countries (2). Decreased fertility began in Europe in the first half of the 19th century starting in France and followed in the second half of the century in the United States and other European countries, Canada, Australia, and New Zealand (3).

Lack of planning is unjustifiable in the twentyfirst century. It is a century in which countries with comprehensive planning and management hold the last word (4).

Undoubtedly, an issue that has engaged the policymakers is population and its growth. As opposed to the past when a country's population represents the majesty of the country, the strength of a powerful country lies with management power (5). Therefore, population growth is a major factor that provides the authorities of a country with the possibility for precise planning (6).

Demographic realities in Iran indicate that family planning objectives in terms of fertility reduction and annual control of the population growth have been fulfilled prior to the determined deadline (7). The crude birth rate in 2011 reached 19 per 1000, and the natural growth rate of population was $1.3 \%$ (8). Hashemi and Salehi-Isfahani showed that family planning failed to delay first childbirth in rural areas in Iran, while it has had a significant effect in reducing higher ranks, particularly the third rank or those above (9).

Therefore, family planning has moved beyond the established purposes. Under these circumstances, measures should be taken to prevent from further fertility reduction.

Fertility has undergone a significant reduction in the past three decades. Today, fertility is at a lower rate than it can be compensated across Iran (10). Total fertility rate of 7 children per woman in 1979 is reduced to 1.9 in 2006 (11). When couples have the opportunity to decide on fertility and its timing, the interval will be farther from marriage to first childbirth (12).

Fertility plays a key role in population growth. Thus, firstly, factors affecting the time-interval between marriage and first childbirth must be studied so that desirable conditions would be yielded by controlling those factors. 
Increased distance as such can have effects on childbirth and fertility in future. Various studies have investigated the trend and changes in fertility and the related factors. The literature shows that the woman's education level (13-15), man's education level (15), and women's age at the time of first marriage (13-15) correlate negatively, while child casualty correlates positively (14), with fertility. The major determinants of the time for first childbirth are the age at marriage (16-20), woman's education level (16-21), the continuation of wives' studies (22), woman's employment after marriage (22), and access to contraception devices (23).

In spite of these findings, we cannot yet find satisfactory answers to the questions concerning the amazingly quick fertility changes in recent years. Therefore, this study aimed to determine the effective factors on the time of first childbirth in married women of Birjand, Iran.

\section{Materials and Methods}

Study Setting

This was a retrospective, prospective cohort study. Written permission was received from Birjand University of Medical Sciences, after which the list of couples registered in Birjand Health Center during 2011 as volunteers for premarriage tests was obtained. Couples who were both from rural areas or those who were not married for any reason, those who were divorced by the study onset (20/04/2015), as well as those who had gone through their second or third marriage, those who had missing contact numbers or location, and those inaccessible by the researchers were excluded from the study. Before entering the study, information was given to all the participants about the goals and questions and in case they agreed to participate, a checklist was completed. Finally, 180 people remained.

Data

The data collection instrument in this study consisted of a checklist which covered such data as the age of woman, the age of man, date of signing the marriage contract, and so forth. The checklist was surveyed through face-to-face interviews or by phone upon receiving consent from the couples. Couples who had no children (until 20/04/2015) were censured.

Analysis

The obtained data were analyzed in STAT-13 software using Cox log-rank test and Cox regression analysis.

\section{Results}

A total of $57.2 \%$ of the participants had children, and the rest were censured (Table 1). Childbirth rates in the first, second, third, and fourth years were $2.2 \%, 16.7 \%, 27.2 \%$ and $10.6 \%$, respectively (Figure 1 ). The mean marriage age in men and women were $25.06 \pm 4.22$ and $21.99 \pm 3.95$ years, respectively.

Table 2 displays the demographic characteristics of the 180 women in terms of having or not having children along
Table 1. Frequency Distribution of Children in Participants

\begin{tabular}{lcc}
\hline & No. & $\%$ \\
\hline Yes & 103 & 57.2 \\
No & 58 & 32.8 \\
Total & 180 & 100 \\
\hline
\end{tabular}

with results from the log-rank analysis. Compared with other groups, the median time-interval from marriage to first childbirth was greater in familial marriage bonds $(P=0.03)$, in women with elementary and secondary education $(P=0.02)$, women born in rural areas $(P=0.03)$, women using IUD method $(P<0.001)$, families with incomes from 500.000 to 1.000 .000 tomans $(P=0.01)$, couples without insurance $(P<0.001)$, and families for whom the child's gender was not important $(P=0.003)$.

Cox regression was used to study the parameters that would influence the time-interval between marriage and the birth of the first child. The results are summarized in Table 3. Factors that affect the time of the birth of the first child consist of man's age at marriage, the timeinterval between signing marriage contract and marriage ceremony, type of marriage, the birthplace of the woman, application of modern methods of contraception, family monthly income, and the desire to have a son. The HR value increased by $7 \%$ as the man's age at marriage increased for a year $(\mathrm{HR}=1.07, P=0.015)$; for each day in the period from contract to marriage ceremony, HR was added by $1 \%(\mathrm{HR}=1.01, P=0.001)$. HR increased by $0.65 \%$ in non-familial marriages $(\mathrm{HR}=1.65, P=0.03$ ) compared with familial ties; it increased $73 \%$ more in the women born in rural areas than those in urban areas (HR $=1.73, P=0.03$ ), and $83 \%$ in families who desired a son $(\mathrm{HR}=1.83, P<0.001)$.

\section{Discussion}

A total of $57.5 \%$ of the respondents had children. The children were born in the first year (2.2\%), in the second year $(16.7 \%)$, in the third year $(27.2 \%)$, and in the fourth year $(10.6 \%)$. Bakht et al reported similar percentages, that are, $29.7 \%, 19.8 \%, 18.7 \%, 12.8 \%$, and $19 \%$ for respective years in their study (24). Abbasi-Shavazi and Razeghi Nasrabad's study showed that over $85 \%$ of women gave birth to their first child in the first 5 years of married life (25). Building on Demographics and Health Survey Project, Razeghi Nasrabad et al reported that over $90 \%$ of women had their first child in the 5 beginning years of married life, that it was not common to have no child in the Iranian society, and that only $2 \%$ of the couples would remain without a child by the 10th year after marriage (16). This rate of infertility approximates the normal levels in population (26). The findings of the current study, therefore, show that women tend to reduce fertility.

The average time-interval between marriage and the birth of the first child in this study was $28.52 \pm 8.85$ months. The study of Fallahzadeh et al in Yazd showed that the average time-interval between births in Yazd 
Table 2. Demographic Characteristics of Women Married in 2011 in Urban Areas of Birjand

\begin{tabular}{|c|c|c|c|c|c|}
\hline \multirow{3}{*}{ Variable } & \multicolumn{3}{|c|}{ With Children } & \multirow{3}{*}{$\begin{array}{l}\text { Without } \\
\text { Children } \\
\text { No. (\%) }\end{array}$} & \multirow{3}{*}{$P$ Value } \\
\hline & \multirow[b]{2}{*}{ No. (\%) } & \multicolumn{2}{|c|}{ First Birth Interval } & & \\
\hline & & Mean \pm SD & Median & & \\
\hline Type of marriage & & & & & 0.03 \\
\hline Familial & $27(26.2)$ & $31.92 \pm 8.06$ & 30.97 & $17(22.1)$ & \\
\hline Non-familial & $76(73.8)$ & $27.3 \pm 8.85$ & 27.33 & 60 (77.9) & \\
\hline Man's education level & & & & & 0.18 \\
\hline Elementary/secondary & $26(25.2)$ & $25.49 \pm 8.94$ & 25.7 & $12(15.8)$ & \\
\hline High school & 37 (35.9) & $29.7 \pm 8.43$ & 31.03 & $26(34.2)$ & \\
\hline Tertiary & $40(38.8)$ & $29.28 \pm 8.95$ & 30.73 & $38(50)$ & \\
\hline Woman's education level & & & & & 0.020 \\
\hline Elementary/secondary & $8(7.8)$ & $28.55 \pm 7.96$ & 25.7 & $6(7.9)$ & \\
\hline High school & $33(32)$ & $26.06 \pm 9.52$ & 31.03 & $14(18.4)$ & \\
\hline Tertiary & $62(60.2)$ & $29.79 \pm 8.46$ & 30.73 & $56(73.7)$ & \\
\hline Man's job & & & & & 0.89 \\
\hline Governmental & $46(44.7)$ & $29.04 \pm 8.68$ & 29.98 & $36(47.4)$ & \\
\hline Non-governmental & $51(49.5)$ & $28.58 \pm 8.69$ & 30.42 & $36(47.4)$ & \\
\hline Unemployed & $6(5.8)$ & $24.04 \pm 11.71$ & 20.03 & $4(5.3)$ & \\
\hline Woman's job & & & & & 0.67 \\
\hline Employed & $15(14.6)$ & $24.49 \pm 9.96$ & 30.25 & $15(19.7)$ & \\
\hline Student & $9(8.7)$ & $33.89 \pm 7.66$ & 34.1 & $18(23.7)$ & \\
\hline Housewife & $79(76.7)$ & $27.72 \pm 8.63$ & 25.7 & $43(56.6)$ & \\
\hline Man's place of birth & & & & & 0.35 \\
\hline Urban & $77(74.8)$ & $29.02 \pm 8.89$ & 30.25 & $61(80.3)$ & \\
\hline Rural & $26(25.2)$ & $27.06 \pm 8.74$ & 26.87 & $15(19.7)$ & \\
\hline Woman's place of birth & & & & & 0.03 \\
\hline Urban & $82(79.6)$ & $29.3 \pm 8.94$ & 30.7 & $71(93.4)$ & \\
\hline Rural & $21(20.4)$ & $25.51 \pm 8$ & 24.43 & $5(6.6)$ & \\
\hline Modern method of contraception & & & & & $<0.001$ \\
\hline Contraceptive pill & $15(41.7)$ & $29.88 \pm 7.34$ & 29.6 & $5(21.7)$ & \\
\hline Condom & $18(50)$ & $29.42 \pm 9.03$ & 30.67 & $18(78.3)$ & \\
\hline Intrauterine device (IUD) & $3(8.3)$ & $10.13 \pm 2.63$ & 10.43 & - & \\
\hline Family monthly income $\mathrm{e}^{\mathrm{b}}$ & & & & & 0.01 \\
\hline$<500000$ & $40(38.8)$ & $26.53 \pm 7.84$ & 26.73 & $19(25.3)$ & \\
\hline 501000 to 1000000 & $48(46.6)$ & $30.53 \pm 9.11$ & 32.68 & $40(53.3)$ & \\
\hline 1 to 1.5 million & $11(10.7)$ & $28.42 \pm 10.15$ & 30.7 & $10(13.3)$ & \\
\hline Over 1.5 million & $4(3.9)$ & $24.09 \pm 8.53$ & 26.5 & $6(8)$ & \\
\hline Abortion experience & & & & & 0.65 \\
\hline Yes & $6(5.9)$ & $30.72 \pm 8.32$ & 30.13 & $8(11.1)$ & \\
\hline No & $96(94.1)$ & $28.43 \pm 8.94$ & 29.97 & $64(88.9)$ & \\
\hline Covered by insurance & & & & & $<0.001$ \\
\hline Yes & $98(95.1)$ & $29.88 \pm 7.61$ & 31.67 & $67(88.2)$ & \\
\hline No & 5 (4.9) & $15.73 \pm 4.33$ & 14.13 & $9(11.8)$ & \\
\hline Desire to have a son & & & & & 0.003 \\
\hline Yes & $50(49)$ & $26.72 \pm 7.95$ & 26.93 & $23(30.7)$ & \\
\hline No & $52(51)$ & $30.49 \pm 9.32$ & 31.8 & $52(69.3)$ & \\
\hline
\end{tabular}

asurvival analysis; log rank test.

$\mathrm{b}$ in Tomans.

is $49.76 \pm 1.82$ months (27). The study of Bakht et al in Hamadan province estimated the average time-interval between marriage and first birth as 24.5 months (24). Abbasi-Shavazi and Razeqi Nasrabad's study showed that the average time-interval between marriage and first birth is 2.7 years across Iran (25). Results of a multilevel analysis indicated that there is a significant difference between different provinces in terms of having the first birth in five years from marriage (16). In a study on Chinese population, Zhenzhen showed that normally there is a two-year time- interval between marriage and the birth of the first child in this country (20). The results from Ngalinda's study showed that the average time-interval between marriage and first birth is 14.5 months on average (23).

Findings of this study showed that the time-interval between marriage contract and the marriage ceremony influences the time of the first childbirth. Given the fact that delay in marriage is not socially and culturally acceptable, women sign marriage contract but lengthen the time interval between the marriage contract and marriage 
Table 3. The Results of Data Analysis Using Cox Regression Analysis

\begin{tabular}{|c|c|c|c|c|}
\hline Variable & B & HR & $95 \% \mathrm{Cl}$ for $\mathrm{HR}$ & $P$ \\
\hline Man's age at marriage & 0.06 & 1.067 & 1.013: 1.124 & 0.015 \\
\hline Woman's age at marriage & 0.04 & 1.046 & 0.994: 1.101 & 0.08 \\
\hline Time-interval between marriage contract and ceremony & -0.003 & 0.997 & 0.996: 0.998 & $<0.001$ \\
\hline $\begin{array}{l}\text { Type of marriage } \\
\text { Familial } \\
\text { Non-familial }\end{array}$ & $\begin{array}{c}0.50 \\
--\end{array}$ & 1.648 & 1.047: 2.593 & 0.031 \\
\hline $\begin{array}{l}\text { Man's education level } \\
\text { Elementary/secondary } \\
\text { High school } \\
\text { Tertiary }\end{array}$ & $\begin{array}{c}0.42 \\
-0.01 \\
--\end{array}$ & $\begin{array}{l}1.526 \\
0.990\end{array}$ & $\begin{array}{l}0.921: 2.530 \\
0.630: 1.555\end{array}$ & 0.154 \\
\hline $\begin{array}{l}\text { Woman's education level } \\
\text { Elementary/secondary } \\
\text { High school } \\
\text { Tertiary }\end{array}$ & $\begin{array}{c}0.16 \\
0.39 \\
--\end{array}$ & $\begin{array}{l}1.179 \\
1.481\end{array}$ & $\begin{array}{l}0.561: 2.478 \\
0.959: 2.286\end{array}$ & 0.03 \\
\hline $\begin{array}{l}\text { Man's job } \\
\text { Governmental } \\
\text { Non-governmental } \\
\text { Unemployed }\end{array}$ & $\begin{array}{c}-0.17 \\
-0.10 \\
--\end{array}$ & $\begin{array}{l}0.839 \\
0.906\end{array}$ & $\begin{array}{l}0.346: 2.035 \\
0.373: 2.203\end{array}$ & 0.19 \\
\hline $\begin{array}{l}\text { Woman's job } \\
\text { Employed } \\
\text { Student } \\
\text { Housewife }\end{array}$ & $\begin{array}{c}-0.24 \\
0.29 \\
--\end{array}$ & $\begin{array}{l}0.782 \\
1.341\end{array}$ & $\begin{array}{l}0.439: 1.396 \\
0.185: 9.718\end{array}$ & 0.10 \\
\hline $\begin{array}{l}\text { Man's place of birth } \\
\text { Urban } \\
\text { Rural }\end{array}$ & $\begin{array}{c}-0.21 \\
--\end{array}$ & 0.807 & 0.515: 1.264 & 0.96 \\
\hline $\begin{array}{l}\text { Woman's place of birth } \\
\text { Urban } \\
\text { Rural }\end{array}$ & $\begin{array}{c}-0.55 \\
--\end{array}$ & 0.577 & $0.352: 0.946$ & 0.21 \\
\hline $\begin{array}{l}\text { Modern method of contraception } \\
\text { Contraceptive pill } \\
\text { Condom } \\
\text { IUD }\end{array}$ & $\begin{array}{c}-4.18 \\
-4.21 \\
--\end{array}$ & $\begin{array}{l}0.015 \\
0.015\end{array}$ & $\begin{array}{l}0.001: 0.157 \\
0.001: 0.151\end{array}$ & 0.66 \\
\hline $\begin{array}{l}\text { Family monthly income } \\
<500000 \\
501000 \text { to } 1000000 \\
1 \text { to } 1.5 \text { million } \\
\text { Over } 1.5 \text { million }\end{array}$ & $\begin{array}{c}-0.46 \\
-1.13 \\
-0.87 \\
--\end{array}$ & $\begin{array}{l}0.633 \\
0.324 \\
0.417\end{array}$ & $\begin{array}{l}0.224: 1.790 \\
0.113: 0.927 \\
0.130: 1.338\end{array}$ & 0.08 \\
\hline $\begin{array}{l}\text { Abortion experience } \\
\text { Yes } \\
\text { No }\end{array}$ & $\begin{array}{c}-0.19 \\
--\end{array}$ & 0.826 & 0.361: 1.892 & 0.89 \\
\hline $\begin{array}{l}\text { Covered by insurance } \\
\text { Yes } \\
\text { No }\end{array}$ & $\begin{array}{c}2.45 \\
--\end{array}$ & 11.581 & 4.118: 32.568 & $<0.001$ \\
\hline $\begin{array}{l}\text { Desire to have a son } \\
\text { Yes } \\
\text { No }\end{array}$ & $\begin{array}{c}0.60 \\
--\end{array}$ & 1.827 & $1.212: 2.753$ & 0.83 \\
\hline
\end{tabular}

ceremony in order to achieve their objectives including higher education level.

The most common contraception method in the participants was the natural method. In the study by Bakht et al, the combined birth control pill was the most common method (24). The most common methods among newly-married couples were the condom in Turkey and Shanghai, and oral contraceptive pills between rural couples of Bangladesh (28-30).
From among the 106 couples who had a child, $36.8 \%$ underwent caesarian section. A similar study in Kohkiluyeh and Boyerahmad province, Iran, in 2003 estimated cesarean section as $32.92 \%$ (31). This was reported as 48\% for the whole country in 2010 (32).

Findings in previous studies have shown that delay in childbearing has a strong correlation with women's age at the time of marriage or their education (16-20). The current study, however, demonstrated that none of these 


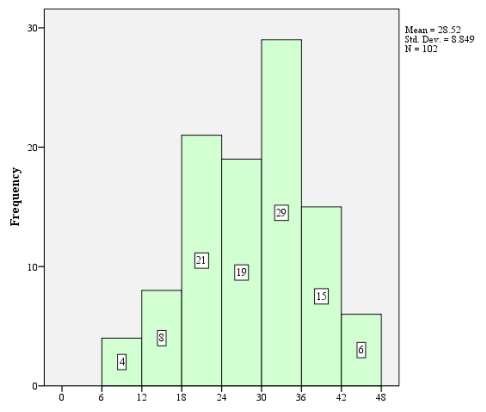

Figure 1. Bar Chart of Time-interval (in Month) From Marriage to First Childbirth

two variables had a significant effect on the time-interval, a finding which corresponds with the results of a study in Taiwan (33). On average, women who have married at a later time than usual have children so earlier than others that the interval to the birth of the first child in the age group below 20 years is $31.1 \pm 8.47$ months, in the age group 20 to 25 years, $27.03 \pm 9.15$ months, and in those older than 25 years, $26.94 \pm 8.47$ months. Bhalotra's study in India confirms this proposition (34).

Age of marriage has a close link with the future size of the family. Those who get married at later years of life would have smaller families. Statistics indicate that in 1966, the age of an Iranian man at the time of marriage was on average 25 and that of the woman was 18.4 years. The same statistics as for the year 2006 was 26.2 years in men and 23.2 in women. In this study, men's and women's mean age were 25.06 and 21.99 years, respectively.

The number of registered marriages in terms of the wife's age at marriage in 2006 was 321.676 cases for the age range of 15 to 19 years and 253412 for the age range of 20 to 24 years. In 2011, the numbers for the same age groups amounted to 281747 and 302,991 cases, respectively (Iran Statistics Center). This shows that the age of marriage has increased. This increasing, particularly among women, can be the cause of fertility decline because it can shorten the reproductive period and thus reduce fertility.

The role of education, especially among women, and its influence on fertility rate have been demonstrated in different studies. In this study, a total of $20.8 \%$ of women were university students before they got married and accordingly failed to have children. Different studies show that educated women postpone marriage for such reasons as involvement in education. Consequently, they give birth to their first child at a longer time and have fewer children. Education provides an individual with knowledge, the power to contemplate on various stages of life, and an introduction to new ideas. It also prepares one for receiving a set of information and ideas about new families. Therefore, educated women have more access to information resources which enables them to have more control over fertility periods. According to a study done by Brand and Davis in the United States, the negative effect of university education only influences the rate of fertility in women belonging to the poor social class with the low level of primary benefit. While for women belonging to other social classes, this relationship is weak (35).

Woman's job after marriage was not an effective variable. According to investigations, a woman's status as an employee, self-employed individual, or student is not as effective as being a housewife in terms of time of first childbirth.

On average, female students experience child delivery later than other females. Most of the women believe that being a student is not compatible with having a child or, at least, they find it undesirable. In other words, women consider education and maternity as two different stages of life which must happen successively rather than simultaneously. Thus, pregnancy will be postponed until education is finished. Having a child coerces women to spend more time on nursing the child at home which, in addition to reducing their participation in the workforce, decreases their job opportunity and thus reduces their participation in the labor market through decreasing their education (36).

The results indicated that income influenced the timeinterval between marriage and first childbirth which is in line with different studies. Economic issues such as job, housing, infrastructure, and so on are the factors which directly or indirectly reduce the tendency to get pregnant or even married. However, a set of other factors are indirectly involved in fertility rate which would have complicated the process of analyzing the issue.

Birthplace of the women influenced the time-interval between marriage and first childbirth such that rural women get pregnant 4 months earlier on average. This finding is in line with the findings of the study conducted by Stokes and Hsieh who reported the difference between the rural and urban women in terms of the time-interval from marriage to first childbirth as 4 months (33).

\section{Conclusions}

At present, women account for more than half of the newly admitted students at universities and they look for employment after graduation. Considerations must be made in such a way that they can have their desired number of children, suitable education, and employment. Couples need to come to the conclusion that there is no conflict between having a child and involvement in education or employment. These two issues are not hierarchical and can take place beside each other. Accordingly, increase in the time-interval between marriage and first childbirth will be reduced and fertility potential will not be impeded.

Emphasis on increasing enjoyment of life on the one hand and stimulation of insatiable appetite of humankind on the media through advertisement of various products and luxury accessories has infused in the youth that all these facilities must be provided on the threshold of marriage in order to enjoy life. Institutionalization of this culture has, in turn, raised expectations of women, men 
and their families, leading ultimately to increased age of marriage.

As it was noted above, a fertility rate that is lower than the substitution power of the society has turned into the dominant state in the Iranian population. Therefore, one can maintain that family planning performance has exceeded the target. In this situation, measures should be taken to prevent further fertility decline. Nothing other than education can be effective in changing the population. Education should start at school, for fertility does not occur as in the past and without proper planning. Rather, it requires long-term planning and happens by choice. Parents are even engaged in the provision of the dowry of their children.

In recent years, women have tended more towards business and income-raising activities; consequently, they now have increased participation in the market. In addition to this, there has occurred a shift in attitude to marriage and maternal as well as matrimonial roles such that these responsibilities are looked down with disdain. This shift in attitude has arisen from feministic and western thought and entered other countries including Iran. It is suggested that in further research, women's views in this regard be surveyed.

\section{Conflict of Interests}

Authors declare that they have no conflict of interests.

\section{Ethical Issues}

The research design was approved by Birjand University of Medical Sciences (Code\#1076) and the code of ethics issued was IR.BUMS.1394.

\section{Financial Support}

Deputy of research and technology, Birjand University of Medical Sciences, Birjand, Iran supported our study.

\section{Acknowledgements}

This paper is extracted from the research proposal approved in Birjand University of Medical Sciences. The authors appreciate the Vice-Chancellery for Research and Technology and the Vice-Chancellery of Health of Birjand University of Medical Sciences.

\section{References}

1. Jokar M. Modernity, lifestyle changes and population decline in Iran. Islamic Journal of Women and Family. 2014;2(2):39-69.

2. McDonald P. Fertility transition hypothesis. In: The Leete R, Alam I, eds. Revolution in Asian Fertility: Dimensions, Causes and Implications. Oxford: Clarendon Press; 1993

3. Hacker JD. Rethinking the "early" decline of marital fertility in the United States. Demography. 2003;40(4):605-620. doi:10.1353/dem.2003.0035

4. Pathak KB, Ram F. Techniques of demographic analysis. New Delhi: Himalaya Pub House; 1992.
5. Bustan MN, Coker AL. Maternal attitude toward pregnancy and the risk of neonatal death. Am J Public Health. 1994;84(3):411-414. doi:10.2105/AJPH.84.3.411

6. Duncan OD. Path Analysis: Sociological Examples. Am J Sociol. 1966;72(1):1-16. doi:10.1086/224256

7. Hosseini H. Economic Demography and Social and Family Planning. Hamedan: Boualisina; 2011.

8. Mather M. US Children in Single-Mother Families. https:// www.prb.org/singlemotherfamilies/. Published May 2010.

9. Hashemi A, Salehi-Isfahani D. Family planning program effects in rural Iran. Blacksburg, USA: Virginia Polytechnic Institute and State University; 2009.

10. Hosseini-Chavoshi M, Abbasi-Shavazi MJ, McDonald P. Fertility, Marriage, and Family Planning in Iran: Implications for Future Policy. 2016;13(1):31-40. doi:10.1515/pophzn-2016-0005

11. Abbasi-Shavazi MJ, McDonald P, Hosseini-Chavoshi M. The fertility transition in Iran: Revolution and reproduction. Springer; 2009.

12. Bumpass LL. Is low fertility here to stay? Fam Plann Perspect. 1973;5(2):67-69. doi:10.2307/2133756

13. Moteeye Haghshnas N. The effect of socio-economic factors and population reproductive behavior in Urmia. Population. 2003;45:46.

14. Kalantari S, Beyk Mohamadi H, Zare Shahabadi A. The population factors affecting women's reproductive population in Yazd, 1383. Women in Development \& Politics. 2005;3(2): 137-159.

15. Mir M Sadeghi J. socio-economic factors affected the recent fertility decline in Iran and some comparison with other MENA countries. The ERF Seventh Conference; Amman, Jordan; 2000

16. Razeghi Nasrabad H, Abbasi-Shavazi MJ, Ghazi Tabtabae S. Multilevel analysis of factors affecting the timing of first births in 1991-2000. Women Strategic Studies. 2012;14:5594.

17. Shayan Z, Ayatollahi SM, Zare N, Moradi F. Prognostic factors of first birth interval using the parametric survival models. Iran J Reprod Med. 2014;12(2):125-130.

18. Gurmu E, Etana D. Early marriage and first birth interval in Ethiopia: Evidences from EDHS. http://paa2010.princeton. edu/papers/101078.

19. Islam M. Differential Determinants of Birth Spacing Since Marriage to First Live Birth in Rural Bangladesh. Pertanika Journal of Social Sciences \& Humanities. 2009;17(1):1-6.

20. Zhenzhen Z. Social-Demographic Influence on First Birth Interval in China, 1980-1992. J Biosoc Sci. 2000;32(3):315327. doi:10.1017/S0021932000003151

21. Hirschman C. Premarital socioeconomic roles and the timing of family formation: a comparative study of five Asian societies. Demography. 1985;22(1):35-59. doi:10.2307/2060985

22. Nomaguchi K. Determinants of Having a First and a Second Child Among Japanese Married Women in Recent Cohorts. University of Maryland at College Park; 2003.

23. Ngalinda I. Age at first birth, fertility, and contraception in Tanzania. Humboldt-Universität Zu Berlin: Philosophische Fakultät III; 1998. 
24. Bakht R, Shaygan Zahedan K, Omidi A. Study of Contraceptive Methods Use before the First Pregnancy. Scientific Journal of Hamadan Nursing \& Midwifery Faculty. 2008;16(2):32-42.

25. Abbasi-Shavazi MJ, Razeghi Nasrabad H. Patterns and influencing factors of the interval between marriage and first birth in Iran. Journal of Population Association of Iran. 2012;5(9):75-105.

26. Vaessen M. Childlessness and infecundity. Voorburg, TheNetherlands: WFS Comparative Studies, International Statistical Institute; 1984.

27. Fallahzadeh H, Farajpour Z, Emam Z. Duration and determinants of birth interval in Yazd, Iran: a population study. Iran J Reprod Med. 2013;11(5):379-384.

28. Bozkurt N, Ozkan S, Onan A, Korucuoglu U, Aygun R, Himmetoglu O. Distribution of contraceptive use in a Turkish population. European Journal of Obstetrics \& Gynecology and Reproductive Biology. 2007;131(1):52-56. doi:10.1016/j.ejogrb.2006.04.004

29. Che Y, Cleland J. Contraceptive use before and after marriage in Shanghai. Stud Fam Plann. 2003;34(1):44-52.

30. Ahmed S, Nahar S. Contraceptive prevalence among adolescent married women in rural Bangladesh.
Mymensingh Med J. 2008;17(1):42-45.

31. Maobaraki A, Zade Bagheri G. Prevalence of Cesarean in Kohgiluyeh and Boyer in 2003. The Iranian Journal of Obstetrics, Gynecology and Infertility. 2005;8(1):73-78.

32. Miri Farahani L, Abbasi-Shavazi MJ. Caesarean Section Change Trends in Iran and Some Demographic Factors Associated with them in the Past Three Decades. J Fasa Univ Med Sci. 2012;2(3):127-134.

33. Stokes CS, Hsieh YS. Female employment and reproductive behavior in Taiwan, 1980. Demography. 1983;20(3):313331. doi: $10.2307 / 2061245$

34. Bhalotra SR, van Soest A. Birth-spacing, fertility and neonatal mortality in India: Dynamics, frailty, and fecundity. J Econom. 2008;143(2):274-290. doi:10.1016/j. jeconom.2007.10.005

35. Brand JE, Davis D. The impact of college education on fertility: evidence for heterogeneous effects. Demography. 2011;48(3):863-887. doi:10.1007/s13524-011-0034-3

36. Musai M, Mehregan N, Rezaee R. Fertility Rate and Women's participation in Labor Force Case Study: Middle Eastern and North African Countries. Women in Development and Politics (research of women). 2012;8(2):55-68.

(c) 2018 The Author (s); This is an open-access article distributed under the terms of the Creative Commons Attribution License (http://creativecommons.org/licenses/by/4.0), which permits unrestricted use, distribution, and reproduction in any medium, provided the original work is properly cited. 